\title{
NOLO CONTENDERE: ITS NATURE AND IMPLICATIONS
}

\author{
NATHAN B. LENVIN* and ERNEST S. MEYERS**
}

IN recent years thousands of defendants have pleaded nolo contendere to indictments and criminal informations charging them with violating the anti-trust laws. ${ }^{1}$ This phenomenon has served to focus attention upon a little known plea of criminal procedure. It has also led to criticism of the Department of Justice for not having insisted on pleas of guilty in its criminal anti-trust prosecutions, especially in the suits which had been brought against important companies in the rubber, magnesium and other war industries. One leading newspaper has characterized the pleas of nolo entered in the Standard Oil case ${ }^{2}$ as consent decrees which left undetermined the guilt of the Standard Oil Company. The general failure to understand the nature of the $\mathrm{plea}^{3}$ is further shown by diverse labels that have been used to describe it, $-\mathbf{a}$ quasi confession of guilt, ${ }^{4}$ an implied confession, ${ }^{5}$ a mild form of pleading guilty, ${ }^{6}$ and a compromise between the defendant and the state. ${ }^{7}$ One law school professor has even termed it "a gentleman's plea of guilty" in view of its recent popular and widespread use. However, an examination of the nature and implications of the plea reveals the error of these conceptions and fully supports the Department's apparent position that the nolo plea is equivalent to a plea of guilty.

The plea was known to the English common law as early as the reign of Henry IV. ${ }^{8}$ The approved statement of its essential characteristics

* Member of the New York Bar, Attorney, Office of Alien Pronerty Custodian.

* Mrember of the New York Bar, Special Assistant to the Attorney General.

The opinions here expressed are solely those of the authors.

1. For example, between July 1, 1941, and June 30. 1942, 47 anti-trust eases involving over a thousand defendants, were terminated as a result of nolo contendere pleas and over $\$ 1,500,000$ were collected in fines.

2. N. Y. Times, April 2, 1942, p. 20, cols. 1-2, referring to United States v. Standard Oil Co. of New Jersey (Crim. Information, D. N. J., MIarch 25, 1942).

3. E.g., in State v. Hopkins, 4 Boyce 306, 307, 88 Atl. 473,474 (Del. Ct. Gen. Sess. 1913) the court stated that by a plea of non-vult contendere the accused "throws himself upon this court to say whether or not he is guily of an infraction of this law." In view of the cases hereinafter cited this statement is patently in error.

4. State v. Burnett, 174 N. C. 796, 93 S. E. 473 (1917).

5. Commonwealth v. Horton, 26 Mass. 206, 207 (1829).

6. Buck v. Commonwealth, $107 \mathrm{~Pa} .486,4 S 9$ (1884).

7. United States v. Glidden Co., 78 F. (2d) 639,642 (C. C. A. Gth, 1935); Tuclier v. United States, 196 Fed. 260, 262 (C. C. A. 7th, 1912).

8. Hen. IV (1399-1413); 11 Hen. IV 65.21, cited in 2 Hawnuss, A Terantse of the Pleas of the Crown (8th ed. 1824) 466. 
at common law is found in Hawkins, A Treatise of the Pleas Of The Crown, ${ }^{0}$ the leading English authority:

"An implied confession is where a defendant, in a case not capital, doth not directly own himself guilty, but in a manner admits it by yielding to the King's mercy, and desiring to submit to a small fine: in which case, if the court think fit to accept of such submission, and make an entry that defendant posuit sc in gratian regis, without putting him to a direct confession, or plea (which in such cases seems to be left to discretion), the defendant shall not be estopped to plead not guilty to an action for the same fact, as he shall if the entry is quod cognovit indictanentum."

Thus, nolo contendere was not a plea in the accepted sense but more in the nature of a petition to the sovereign's mercy. Although the plea or petition developed as a part of the common law, it has in England fallen into the discard, and since 1702 no instance of its entry has been found. ${ }^{10}$ In the United States, its continued use has not led to any radical alteration of the accepted definition of the plea as stated by Hawkins, ${ }^{11}$ but, as has been pointed out, misunderstandings concerning its use and consequences persist.

Federal and state decisions are in agreement that the plea cannot be entered by the defendant as a matter of right, and that its acceptance by the court is entirely a matter of grace. ${ }^{12}$ As with other pleas, once nolo contendere has been accepted, it is discretionary with the court whether the plea may be withdrawn and replaced by another form of pleading. ${ }^{13}$ In a comparatively recent case, ${ }^{14}$ the defendant attempted to

9. 2 Hawkins, op. cit. supra note 8 , at 466 . 1702).

10. The last reported English case is The Queen v. Templeman, 1 Salk. 55 (Q. B.

11. The plea has been defined as "a formal declaration by the accused that he will not contest the charge against him. It is an implied confession of guilt and, for the purposes of the case only, is equivalent to a plea of guilty. It is not open to the accused in all cases, and is allowable only by leave of court . . . The difference between it and a plea of guilty appears to be simply that, while the latter is a confession binding ac cused in other proceedings [i.e., defendant is estopped from denying his guilt], the former has no effect beyond the particular case. It is an implied confession of guilt only, and cannot be used against accused as an admission in any civil suit for the same act." 22 C. J. S., $\$ 425$, p. $658-659$.

12. Hudson v. United States, 272 U. S. 451 (1926); Twin Ports Oil Co. v. Pure Oil Co., 26 F. Supp. 366 (D. Minn. 1939); United States v. Socony-Vacuum Oil Co., Inc., 23 F. Supp. 531 (W. D. Wis. 1938); United States v. Lair, 195 Fed. 47 (C. C. $\Lambda$. 8th, 1912) ; Commonwealth v. Horton, 26 Mass. 206 (1829); Commonwealth v. Ingersoll, 145 Mass. 381, 14 N. E. 449 (1888) ; Williams v. State, 130 Miss. 827, 94 So. 882 (1922); State v. Martin, 92 N. J. L. 436, 106 Atl. 385 (Ct. Errors and App. 1919); MeNab v. State, 42 Wyo. 396, 295 Pac. 278 (1931).

13. Commonwealth v. Marino, 254 Mass. 533,150 N. E. 841 (1926) ; State v. Sid. dall, 103 Me. 144, 68 Atl. 634 (1907); in re Lanni, 47 R. I. 158, 131 Att. 52 (1925). But cf. Fox v. State, 112 Fla. 104, 150 So. 228 (1933) (defendant interposed plea of nolo 
substitute a plea of not guilty for a plea of nolo contendere previously filed. After a motion to withdraw the plea had been rejected, the defendant sought to regain his freedom in a subsequent habeas corpus proceeding, on the theory that he had been denied a jury trial. But the court held that "a jury trial was waived by making that plea. . . . Lilie a plea of guilty, it may be withdrawn only if the court allows it."

In an ordinary case, the acceptance of a plea of nolu contendere has the same consequences as a plea of guilty. ${ }^{15}$ Imposition of sentence follows as a matter of course, ${ }^{16}$ and only testimony bearing on the issue of punishment can be submitted to the court. ${ }^{17}$ One court has succinctly described the ensuing procedure in this fashion: ${ }^{18}$

"The judgment follows as well the one plea [nolo contendere] as the other [guilty] . . . It is not necessary that the court should adjudge that the party was guilty for that follows by necessary legal inference from the implied confession."

As a corollary to the above practice, when the plea has been accepted, it is not within the province of the court to adjudge the defendant guilty or not guilty. ${ }^{19}$ In one state case it was held to be reversible error for a trial judge to accept the plea in part and then to hear evidence, not to determine the extent of punishment, but to ascertain the guilt or innocence of the defendant. The appellate court stated, as the ground for its reversal of the trial court, that "evidence is heard only to aid the judge in fixing sentence." 20 And, as in the case of a plea of guilty, the court, if convinced of the defendant's innocence, may advise him to move to withdraw the plea of nolo contendere in favor

contendere without understanding the legal effect of the plea; denial by the trial cuurt of the defendant's motion to withdraw the plez held to be errur).

14. Farnsworth v. Zerbst, 97 F. (2d) 255 (C. C. A. 5th, 1938), relicaring denicd, 98 F. (2d) 541 (C. C. A. 5th, 1938).

15. Pharr v. United States, 48 F. (2d) 767 (C. C. A. Gth, 1931); Crowley v. United States, 113 F. (2d) 334 (C. C. A. Sth, 1940); United States v. Lair, 195 Fed. 47 (C. C. A. 8th, 1912); Commonwealth v. Ingersoll, 145 Mass. 381, 14 N. E. 449 (188s); Commonwealth v. Jackson, 248 Pa. 530, 94 Atl. 233 (1915); State v. Siddall, 103 Mle. 14, 68 Atl. 634 (1907); Schad v. MicNinch, 103 W. Va. H4, 136 S. E. 865 (1927); State v. Suick, 195 Wis. 175,217 N. W. 743 (192S).

16. Commonwealth v. Ingersoll, 145 Mass. 381,14 N. E. 449 (1843); Commonwealth v. Holstine, $132 \mathrm{~Pa} .357,19$ Atl. 273 (1890).

17. State v. Burnett, 174 N. C. 796,93 S. E. 473 (1917).

18. Commonwealth v. Horton, 26 Mass. 206, 208 (1829).

19. Ferguson v. Reinhart, $125 \mathrm{~Pa}$. Super. 154, 190 Atl. 153 (1937); State v. Herlihy, 102 Me. 310, 66 Atl. 643 (1906).

20. Crowley v. United States, 113 F. (2d) 334,338 (C. C. A. 8th, 1940); Cummonwealth v. Rousch, $113 \mathrm{~Pa}$. Super. 182, 172 Atl. 484 (1934). In Roitman v. United States, $41 \mathrm{~F}$. (2d) 519 (C. C. A. 7th, 1930), rendition of a judgment of guilty after a plea uf nolo contendere was held to be at most superfluous, and not error even thuugh testimony bearing on the the defendant's guilt was taken after the plea was entered. 
of one of not guilty. ${ }^{21}$ Further, the plea of nolo contendere, like the demurrer, admits for the purposes of the case, all facts that are well pleaded. $^{22}$

There are few reported cases in this country in which the acceptability of a plea of nolo contendere has been litigated. Those that have been decided, however, raise two important problems. The question most frequently considered by court and counsel is whether a defendant can be imprisoned after a plea of nolo contendere to an offense where imprisonment is an alternative punishment; a collateral issue is whether the plea can be accepted at all in a case where imprisonment is mandatory, i.e., a felony case.

All courts, both state and federal, have held that, in the absence of statute, the plea cannot be interposed to an indictment for a capital offense. ${ }^{23}$ This limitation stems from the statement of Hawkins limiting the applicability of the plea to "cases not capital". A rationale for the restriction has been found in the theory that, where extreme penalties arc to be imposed, the law should be particularly scrupulous to "throw about the accused every reasonable protection." His guilt should be established beyond all reasonable doubt, and "an implied confession of guilt cannot rise to the degree of certainty which would make it the equivalent of an express confession." 24

As to whether the plea may be invoked in felony cases, the courts seem to be divided along three principal lines: some jurisdictions will accept the nolo plea in felony cases $;^{25}$ others limit its applicability to "light" misdemeanors and feel constrained to limit punishment to a fine $;^{26}$ and still others will not accept the plea in felony cases, but will

21. Of course, it would be improper to adjudge the defendant not guilty. See Commonwealth v. Rousch, $113 \mathrm{~Pa}$. Super. 182, 172 Atl. 484 (1934); Ferguson v. Reinhart, $125 \mathrm{~Pa}$. Super. 154, 190 Atl. 153 (1937).

22. State v. O'Brien, 18 R. I. 105,25 Atl. 910 (1892).

23. Hudson v. United States, 272 U. S. 451 (1926); Tucker v. United States, 196 Fed. 260 (C. C. A. 7th, 1912); Commonwealth v. Shrope, 264 Pa. 246, 107 Atl. 729 (1919); Commonwealth v. Ferguson, $44 \mathrm{~Pa}$. Super. 626 (1910); Roach v. Commonwealth, 157 Va. 954, 162 S. E. 50 (1932) ; State v. Kiewel, 166 Minn. 302, 207 N. W. 646 (1926); Williams v. State, 130 Miss. 827, 844, 94 So. 882, 884 (1922). But cf. State v. Martin, 92 N. J. L. 436, 106 Atl. 385 (Ct. Errors and App. 1919) (By statute the New Jersty courts may accept a plea of nolo contendere to an indictment for first degree murder; if accepted, the charge is automatically reduced to second degree murder, imprisonment for life being the punishment specified).

24. Commonwealth v. Shrope, 264 Pa. 246, 250, 107 At1. 729, 730 (1919).

25. See, e.g., the federal courts [Hudson v. United States, 272 U. S. 451 (1926)]; Massachusetts (Stat. 1855, c. 215, § 35); New Jersey [State v. Martin, 92 N. J. L. 436, 106 Atl. 385 (Ct. Errors and App. 1919)]; Pennsylvania [Commonwealth v. Ferguson, $44 \mathrm{~Pa}$. Super. 626 (1910)]; Rhode Island [In re Lanni, 47 R. I. 158, 131 Atl. 52 (1925)].

26. See, e.g., Virginia [Roach v. Commonwealth, 157 Va. 954, 162 S. E. 50 (1932)]; Minnesota [State v. Kiewel, 166 Minn. 302, 207 N. W. 646 (1926)]; Mississippi [Williams v. State, 130 Miss. 827,94 So. 882 (1922)]. 
impose prison sentences after the plea has been accepted in an action charging an offense for which imprisonment is an alternative punishment. $^{27}$

In the federal courts the issue of the availability of the plea was squarely presented for the first time in Tucker \%. United States, ${ }^{23}$ where the defendant had been indicted for violation of the Internal Revenue Act. After a plea of nolo contendere, the defendant was sentenced to prison and fined. On appeal, two questions were certified to the Court of Appeals for the Seventh Circuit: first, whether acceptance of a plea of nolo contendere precludes sentence of imprisonment; and, second, whether a court may accept such a plea when the offense is one for which imprisonment is mandatory. The first question was answered in the affirmative, the second in the negative. In the absence of a federal rule regulating the plea, the Court rested its judgment upon its interpretation of the common law. It concluded that the plea was not applicable in those cases where imprisonment was mandatory, but could be accepted where imprisonment was an alternative punishment, and, if accepted in the latter case, the Court could only impose a fine. Thus, basing its holding on Hawkins' statement of "desiring to submit to a small fine," the Circuit Court of Appeals reasoned that only a fine could be imposed, and a fortiori if the offense were one where imprisonment was compulsory, the plea could not be accepted.

On the first point, the Tucker case was repudiated by the United States Supreme Court in Hudson v. United States. ${ }^{29}$ In the Hudson case, the defendants were indicted for using the mails to defraud, a felony punishable by fine or imprisonment or both, and, after pleading nolo contendere. each defendant was sentenced to imprisonment for a year and a day. Again, as in the Tucker case, the question was raised "whether a United States court, after accepting a plea of nolo contendere, may impose a prison sentence?" The Supreme Court, replying in the aftirmative, held Hawkins' statement, "desiring to submit to a small fine", illustrative only and not a condition binding on the tribunal. The Court declared:

"There is no suggestion that would warrant the conclusion that a court, by the mere acceptance of the plea of nolo contendere, would be limited to a fine in fixing sentence. . . .

"We think it clear, therefore, that the contention now pressed upon us not only fails of support in judicial decisions, other than those of the seventh circuit already noticed, but its historical background is too meager and inconclusive to be persuasive in leading us to adopt the limitation as one recognized by the common law.

27. See, e.g., West Virginia [Schad v. ArNinch, 103 W. Va. 44, 49, 136 S. E. 865 , 867 (1927)]; Wisconsin [Brozosky v. State, 197 Wis. 446, 451, 222 N. W. 311, 312 (1928)].

28. 196 Fed. 260 (C. C. A. 7th, 1912).

29. 272 U. S. $451,456-457$ (1926). 
"Undoubtedly a court may, in its discretion, mitigate the punishment on a plea of nolo contendere and feel constrained to do so whenever the plea is accepted with the understanding that only a fine is to be imposed. But such a restriction made mandatory upon the court by positive rule of law would only hamper its discretion and curtail the utility of the plea." 30

The Supreme Court did not expressly decide whether the plea is permissible in cases where punishment by imprisonment is mandatory. But on this point, too, the Tucker case was apparently overruled, since it was stated that the "use of the plea" and "the propriety of imposing" a prison sentence upon it are recognized by the Probation Act, ${ }^{31}$ which provides for the suspension of sentence and the release of the prisoner on probation . . . 'after a plea . . . of nolo contendere for any crime or offense not punishable by death or life imprisonment." "

While the decision in the Tucker case was followed in some jurisdictions, $^{32}$ it was not the accepted rule, prior to the decision in the Hudson case, in the Federal Circuit Courts of Appeals. Thus, in United States v. Lair, ${ }^{33}$ the Court of Appeals for the Eighth Circuit did not question the acceptance of a plea of nolo contendere to an indictment charging the importation of an alien prostitute, and affirmed the sentence of two years and fine of $\$ 2,500$. The rule enunciated in the Hudson case, ${ }^{\text {d4 }}$ that prison sentences can be imposed after a nolo plea, has, since that decision, been consistently followed in the federal courts. In Crowley v. United States, ${ }^{35}$ the defendants were indicted for mail fraud and sentenced to prison and fined after their plea of nolo contendere. The Court said that "it is settled that the pleas of nolo contendere were confessions of guilt for the purpose of the case, and sentence of both imprisonment and fine could be imposed upon such a plea."30 Similarly, in Farnsworth $\%$. Sanford, ${ }^{37}$ the defendant, after pleading nolo contendere to an espionage indictment, sought release by a petition for habeas corpus, claiming that no valid plea of nolo contendere could be made where the offense charged was punishable by a mandatory penalty of imprisonment. But, relying on the Hudson case, the Court rejected this contention. The established rule is further

30. Ibid.

31. 43 STAT. 1259 (1925), 18 U. S. C. $\$ 724$ (1940).

32. See cases cited sttpra note 27.

33. 195 Fed. 47 (C. C. A. 8th, 1912).

34. 9 Hughes, Federal Practice (1941 Supp.) § 7089 thus states the rule: "Though a plea of nolo contendere does not create an estoppel, it has all the effect of a plea of guilty for the purposes of the particular case, so that any punishment, including imprisonment, may be imposed which would be permissible under a plea of guilty . . ."

35. 113 F. (2d) 334 (C. C. A. 8th, 1940).

36. Id. at 338 .

37. 33 F. Supp. 400 (N. D. Ga. 1940). 
illustrated by a recent case, ${ }^{38}$ in which the Securities and Exchange Commission charged a conspiracy to violate the anti-manipulative provisions of the Securities Exchange Act of 1934. On a plea of nolo contendere the defendants were given suspended prison sentences of two years and fined $\$ 10,000$.

The state courts are in hopeless disagreement on these issues. Several jurisdictions take the extreme position that no recognition can be accorded the plea of nolo contendere in any event. This is either because there is no provision for the plea in the criminal statutes of the state, and hence, by implication, it is not available to the defendant, ${ }^{\text {,3 }}$ or because the plea has been outlawed by statute. ${ }^{40}$ In jurisdictions where the plea is recognized, it is settled in Pennsylvania, ${ }^{11}$ New Jersey, ${ }^{32}$ Rhode Island, ${ }^{43}$ and Massachusetts ${ }^{44}$ that the plea can be interposed to a felony indictment, and, thus, a prison sentence can be imposed after a plea of nolo contendere. In West Virginia ${ }^{45}$ and Wisconsin, ${ }^{46}$ it is not clear whether the plea would be accepted if interposed to a felony indictment. However, these jurisdictions have admitted the plea in cases involving misdemeanors, and have imposed prison sentences where imprisonment is an alternative mode of punishment. Other states will accept the plea only for a misdemeanor and after its acceptance have limited the punishment to a fine. ${ }^{47}$ The reason for this holding is, as stated by a Virginia court, that since there is no statutory provision for the plea, the common law must prevail :

38. See Securities Exchange Act of 1934, Release No. 3020, Sept. 25, 1941.

39. People v. 1riller, 264 IIl. 148, 105 N. E. 191 (1914); State v. Kiewel, 166 Minn. 302, 207 N. W. 646 (1926); Miahoney v. State, 197 Ind. 335, 149 N. E. 444 (1925); State v. Hill, 145 Kan. 27, 64 P. (2d) 71 (1937). A contrary result is reached in Wyoming, where it has been held that the common law recognition of the plea is not inconsistent with the statute for criminal procedure that fails to make specific provision for it. See MícNab v. State, 42 Wyo. 396, 295 Pac. 278 (1931).

40. People v. Daiboch, 265 N. Y. 125, 191 N. E. 859 (1934). It is interesting to note that even though New York has abolished the plea of nolo contendere it gives extraterritorial effect to the plea. See note 61 infra.

41. Commonwealth v. Ferguson, H Pa. Super. 626 (1910); Teslovich v. Fireman's Fund Ins. Co. of San Francisco, 110 Pa. Super. 245, 168 Atl. 354 (1933); Commonwealth v. Shrope, $264 \mathrm{~Pa} .246,107$ Atl. 729 (1919).

42. State v. Martin, 92 N. J. L. 436, 106 Atl. 385 (Ct. Errors and App. 1919); State v. Alderman, 81 N. J. L. 549, 79 Atl. 283 (Ct. Errors and App. 1911).

43. Barker v. Almy, 20 R. I. 367,39 Atl. 185 (1898); Orabona v. Linscott, 49 R. I. 443, 144 Atl. 52 (1928); In re Lanni, 47 R. I. 158, 131 Atl. 52 (1925).

44. Commonwealth v. Horton, 26 Miass. 206 (1829); Commonwealth v. Ingersoll, 145 Miass. 381, 14 N. E. 449 (1888); Commonwealth v. Adams, 72 Mass. 359 (1856); Commonwealth v. Marino, 254 Mass. 533, 150 N. E. $\$ 41$ (1920).

45. Schad v. 1 IcNinch, 103 W. Va. 44, 136 S. E. 865 (1927).

46. Brozosky v. State, 197 Wis. 446, 222 N. W. 311 (1928).

47. Roach v. Commonwealth, 157 Va. $954,960,162$ S. E. 50,52 (1932); Williams v. State, 130 Miss. 827,94 So. 882 (1922). 
"In Virginia there is no such distinction between 'capital cases' and 'felonies', as exists in some jurisdictions or as existed at common law... 'Such offenses as are punishable with death or confinement in the penitentiary are felonies; all other offenses are misdemeanors.' . . . Under the prevailing law in this state a plen of nolo contendere cannot be accepted in a felony case." 48

Disregarding for the moment the pronouncement of the various courts on the question of whether a plea of nolo contendere can be interposed to an indictment for a crime where a prison sentence is mandatory, and using, as the courts have done, the statement of Hawkins as the rationale, it does not seem illogical to argue that the plea should be applicable to non-capital felony cases. Hawkins limits the applicability of the plea to "cases not capital". This does not exclude all felonies where capital punishment is prescribed. Parenthetically, the statement that defendant "wishes to submit to a small fine" expresses only one of the reasons why a defendant interposes the plea - it is only a hope and a desire on the part of the defendant, certainly not binding on the court. ${ }^{40}$ As one court has pointed out, ${ }^{50}$ there is an erroneous impression that under the

48. Roach v. Commonwealth, 157 Va. 954, 960, 162 S. E. 50, 52 (1932). Several commentaries support this position by limiting the applicability of the plea to light misdemeanors. See 2 Bishop, New Criminal Procedure (2d ed. 1913) §802; Arcibold's Pleading, Evidence, ANd Practice (26th ed. 1922) 379.

49. The state cases which limit the power of the Court to the imposition of a fine fail to note that the recital in 2 Hawnins, op. cit. supra note 8 , on which these decisions have been predicated, is a petition for mercy-not a limitation upon the power of the Court. See Brozosky v. State, 197 Wis. 451, 222 N. W. 311 (1928).

50. In United States v. Coppersmith, 4 Fed. 198, $201-203$ (C. C. W. D. Tenu. 1880) the following definition of "felony" is given: "The word 'felony' appears to have been long used to signify the degree or class of crime committed, rather than the penal consequences of the forfeiture occasioned by the crime according to its original signification ... .

"Capital punishment by no means enters into the true definition of felony. Strictly speaking, the term comprised every species of crime which occasioned at common law the total forfeiture either of lands or goods or both. That was the only test. Felonics by common law are such as either concern the taking away of life, or concern the taking away of goods, or concern the habitation or concern the obstruction of the execution of justice in criminal and capital causes, as escapes, rescues, etc. 1 Hale's P. C. $411 \ldots$ The superadded punishment was either capital or otherwise, according to the degree of guilt; that is, the turpitude of the offense. There were felonies not punishable by death, and on the other hand thete were offenses not felonics which were so punishable. However, the idea of felony was so generally connected with capital punishment, that, erroneously, it came to be understood that all crimes punishable with death were felonies; and so, if a statute created a new offense and called it a felony, but prescribed no punishment, by implication of law it was punishable with death . . . In American law, forfeiture as a consequence of crime being generally abolished, the word 'felony' has lost its original and characteristic meaning, and it is rather used to denote any high crime punishable by death or imprisonment . . ." See Considine v. United States, 112 Fed. 342, 344 (C. C. A. 6th, 1901). 
common law all felonies are punishable by death, i.e., were capital crimes. Many early statutes creating felonies did not prescribe punishment and it is only by implication that these crimes were punishable by death. Further, if the plea is accepted where imprisonment is an alternative punishment and such punishment can be and is imposed, it is not inconsistent to accept the plea where imprisonment is mandatory. In such cases the defendant, by resorting to this plea rather than one of guilty, is benefited by not being estopped to deny the facts in a subsequent civil suit based on the same illegal activity. Thus, in Teslozich a'. Fireman's Fund Insurance Company, ${ }^{\text {b1 }}$ the plaintiff sued for damages resulting from fire on property covered by the defendant insurance company. The action was defended on the ground that in a prior action the plaintifi had been indicted for arson and convicted under the plea of nolo. In rejecting the odefendant's offer of proof of the entry of the plea to establish that the fire was caused by the plaintiff in order to defraud the insurance company, the Court held that the conviction under the plea of nolo contendere could not be used against the plaintiff as an admission in any civil suit concerning the same act.

Thus, the only basic characteristic of the plea of nolo contendere which differentiates it from a guilty plea is that the defendant is not estopped from denying the facts to which he pleaded nolo contendere in a subsequent judicial civil proceeding..$^{52}$ Apart from this immunity a number of situations indicate that the consequences of the plea are not unlike those of a plea of guilty.

In making pleas of nolo contendere defendants generally have hoped to mitigate their punishment and undoubtedly have believed, or have been advised, that their obligation to society would be settled by means of this process. A persuasive factor, also, is the lnowledge that the plea does not estop the defendant from denying the facts in a subsequent civil action growing out of the same alleged misdeed. Moreover, the expense of defending a long criminal prosecution and the stigma attached to a guilty plea or conviction after trial can be avoided. But examina-

51. Teslovich v. Fireman's Fund Ins. Co. of San Francisco, 110 Pa. Super. 245, 169 Att. 354 (1933).

52. In 4 Coaryns, A Digest of tae Laws of Engl.wing (4th ed. 1793), under Indictment, c. K, Confession, p. 38S, it is stated: "So, a man may ponere se in gratiam regis, and pray that he may be admitted by fine. $9 \mathrm{H}$. 6.603. And such a confession does not conciude him. $9 \mathrm{H} .6,60$ a." See Peonle ax rel. Attorney General v. Edison, 100 Colo. 574, 577, 69 P. (2d) 246, 248 (1937) (Here a prior plea of nolo contendere to a charge of perjury was not admitted against the defendant in a subsequent disbarment proceeding. The court held: "The plea of nolo contendere entered in the forum of the indictment, while effective for sentence there, was not otherwise or elsewhere conclusive."); Twin Ports Oil Co. v. Pure Oil Co., 26 F. Sugp. 3\&6, 376 (D. Minn. 1939) ; Fidelity-Phoenix Fire Ins. Co. of New York v. Murphy, 231 Ala. 6S0, 686, 166 So. 604, 609 (1936) ; Teslovich v. Fireman's Fund Ins. Co. of San Francisco, $110 \mathrm{~Pa}$. Super. 245, 250, 168 Atl. 354, 355 (1933); 2 Hawmss, op. cit. suspra note $8, b k .2$, c. 31 . 
tion of the legal implications of the plea demonstrates that the plea can have disturbing consequences.

The adjudicated cases suggest several questions: What is the effect of a prior plea of nolo contendere on the status of one convicted for another crime in a jurisdiction providing for increased penalties for multi-offenders? Can a nolo contendere plea be introduced to impeach a witness' credibility in a subsequent action? What is the effect in a state criminal anti-trust action of a plea of nolo to a federal anti-trust indictment? And does a previous plea of nolo contendere amount to a conviction under the numerous forms of questionnaires which are required of the average individual, - "Have you ever been convicted of a crime?"

It is clear that the entry of a plea of nolo contendere constitutes at conviction making an individual, after a subsequent convittion, a multioffender. This proposition was established in People $\%$. Daiboch ${ }^{53}$ where the defendant had pleaded guilty to an indictment for forgery and was sentenced to the state penitentiary. Later it was discovered that he had previously pleaded nolo to a felony charge in another jurisdiction and he was re-sentenced as a second offender. The Appellate Division of the State of New York decided that, since the defendant had been convicted under a plea of nolo contendere, he was not a second offender within the meaning of the applicable statute. In reversing the intermediate court, the New York Court of Appeals stated that a nolo contendere plea is a conviction and makes a person, after a second conviction, a second offender..$^{54}$ To the same effect is State $v$. Suick. ${ }^{56}$ There the defendant pleaded nolo to violating the state liquor law, and later pleaded guilty to another similar offense. The Court rejected the defendant's contention, that the first judgment did not amount to a prior conviction, in these words:

"The effect of this judgment between the parties depends in no manner upon the proceedings which lead up to the rendition of the judgment. The force and effect of the judgment is just the same whether the defendant pleaded guilty, was found guilty by a verdict of a jury, or whether judgment followed a plea of nolo contendere. . . . It is a plea, however, from which a judgment of conviction follows as inevitably as such judgment follows a plea of guilty."

United States ex rel. Bruno v. Reimer, Commissioner of Immigration, ${ }^{60}$ indicates that federal courts will treat a nolo contendere plea as a convic-

53. 265 N. Y. $125,129,191$ N. E. 859,860 (1934).

54. Contra: People v. Miller, 264 Ill. 148, 154, 106 N. E. 191, 194 (1914).

55. 195 Wis. $175,177,217$ N. W. 743,744 (1928). To the same effect is Brozosky v. State, 197 Wis. $446,451,222$ N. W. 311,312 (1928).

56. 98 F. (2d) 92 (C. C. A. 2d, 1938). See also Gemignani v. United States, 9 F. (2d) 384 (C. C. A. 6 th, 1925). 
tion in a situation similar to that in the Daibock case. In the Rcincer case, the defendant had been indicted for robbery in New Jersey and under a plea of nolo contendere was sentenced to a reformatory. Subsequently, he was indicted for robbery and pleaded guilty. While serving the sentence given him in the second action, a deportation warrant was issued on the ground that the defendant had been twice sentenced to serve more than a year for crimes involving moral turpitude. On appeal from the deportation order, the defendant asserted that the first sentence, not being upon a plea of guilty, was not a sentence of conviction within the meaning of the deportation statute. The defendant also argued that his nolo plea admitted the truth of the facts charged in the indictment solely for the purpose of the prosecution and, therefore, should not be considered in the deportation proceeding, a collateral matter. Both of these contentions were overruled by the Court, which said:

"It is true that the plea is not treated as a confession, which can be used against the accused elsewhere; but it gives the judge as complete power to sentence as a plea of guilty. . . . And it is as conclusive of guilt for all purposes of prosecution under the indictment. . . Moreover, a sentence upon it is a conviction within the terms of a local statute applying to second offenders" (citing the Daiboch case).

The conclusion is, therefore, inescapable that a plea of nolo contendere not only has the same force and effect as a conviction under a plea of guilty insofar as it constitutes a conviction making the accused a second offender, but also subjects the accused to all the penalties of being a multiple offender where all convictions resulted from pleas of nolo contendere.

A previous conviction under a plea of nolo contendere had been held admissible to attack the credibility of a witness. In State $w^{\text {. Herlihy, }}$ the defendant was indicted for keeping intoxicating liquors. At the trial, evidence of a former conviction under a plea of nolo contendere was introduced in order to impeach the credibility of the defendant who had taken the stand in his own defense. Defendant's counsel urged that evidence of his former conviction was not admissible since there had been, under the nolo plea, no adjudication of his guilt. The Court properly rejected this contention. A closely related problem was raised in Commonwealth ex rel. District Attoritey v. Jackson. ws On a prior occasion the defendant had pleaded nolo to an indictment charging

57. 102 Mie. 310, 66 Atl. 643 (1905).

58. $248 \mathrm{~Pa}$. 530, 94 Atl. 233 (1915). See also Commonwealth v. Horton, 26 Mass. 206 (1829); States v. Hartwell, 26 Fed. Cas. 196, No. 15,318 (C. C. D. Miass. 1869); United States ex rel. Bruno v. Reimer, 98 F. (2d) 92 (C. C. A. 2d, 1933); Barler $:$ Almy, 20 R. I. 367, 39 Atl. 185 (189S). Contra: Doughty v. Amorel, 22 R. I. 158, 46 Atl. $\$ 38$ (1900). 
him with accepting bribes as a member of a school board. Quo zuarranto proceedings were subsequently instituted under a statute providing for removal of board members in the event of a conviction for accepting bribes, and the Court upheld the petition.

As yet no court has considered the admissibility of evidence of a plea of nolo in the situation presented in Myers $v$. United States. ${ }^{50}$ There it was held that evidence of a plea of guilty in a state court to the charge of possession of liquor was properly admissible in a criminal prosecution in the federal court for the illegal sale of the liquor by the same defendant. Despite absence of authority on the precise point, admission of evidence of a prior plea of nolo in this situation would also seem unobjectionable. A similar issue arises in determining the effect of a nolo plea to a federal anti-trust indictment in a subsequent state criminal anti-trust action for the same offense. It is likely that a defendant who has violated the federal anti-trust laws has by the same acts violated the applicable state statute. ${ }^{60}$ In this situation, the nolo plea would constitute a conviction in the same sense as a conviction after a plea of guilty or after a verdict of guilty by a jury, and, therefore, by analogy to the Myers case, be admissible as a confession or admission in the state action. ${ }^{61}$ On the other hand, if the action in the state court were instituted under a state statute providing for forfeiture of the corporate charter or the right to do business in the state by a foreign or domestic corporation violating the state anti-trust law, then the action would be a civil one and the defendant would not, in the absence of statutory provisions to the contrary, be estopped from denying the facts to which he had previously pleaded nolo in either the federal or state courts. This common law proposition seems to have been given legislative sanction in an amendment to the federal anti-trust laws, ${ }^{62}$ and,

59. 49 F. (2d) 230 (C. C. A. 4th, 1931), cert. denied, 283 U. S. 866 (1931).

60. In addition to the problem outlined above, a related problem arises where, as is the case in a few states, the state antitrust laws provide that the corporate charter is to be revoked where the corporation has twice been convicted of violating the state antitrust laws. In this connection, if either of the two convictions has bcen by way of a plea of nolo contendere it would seem that the charter would be forfeited. Cf. Pcople v. Daiboch, 265 N. Y. 125,191 N. E. 859 (1934).

61. A few jurisdictions that prohibit the use of the nolo plea will not recognize its extraterritorial effect in a subsequent proceeding against the same defendant. Sec Pcople v. Miller, 264 Ill. 148, 154, 106 N. E. 191, 194 (1914). (This case raises a conflict of laws problem; it holds that since the plea of nolo contendere is not recognized in Illinois, the admission in evidence of a prior conviction obtained under a plea of nolo contendere is error). The New York rule is contra; in that jurisdiction the plen of nolo contendere has also been outlawed. See People v. Daiboch, 265 N. Y. 125, 191 N. E. 859 (1934).

62. 38 Stat. 731 (1914), 15 U. S. C. § 16 (1940): "A final judgment or decrce hereafter rendered in any criminal prosecution or in any suit or proceeding in cquity brought by or on behalf of the United States under the antitrust laws to the effect that 
as a result, a nolo plea has been held not to be prima facie evidence of the defendant's guilt in a subsequent suit for statutory treble damages. ${ }^{\text {(3) }}$ Congress in the Clayton $\mathrm{Act}^{04}$ has given private persons, injured by violations of the anti-trust laws, ${ }^{65}$ the benefit of proceedings instituted by the Government. In suing for statutory treble damages the injured party may use a final judgment or decree in the Government's case as prima facie evidence against the same defendants. ${ }^{60}$ In a leading case involving this point, the intention to save the injured party the expense and burden in litigation has been held not to apply to "consent judgments or decrees entered before any testimony has been taken." And the nolo plea was considered to be such a "consent judgment", so that it was within the statutory immunity and not available to the damaged party as prima facie evidence of the pleader's guilt. ${ }^{67}$ In arriving at its decision the court was undoubtedly influenced greatly by the language of the statute - "before any testimony has been taken" - , for nolo contendere can hardly be treated as a "consent judgment" in the manner of a "consent decree" in a civil action. A "consent decree" in antitrust proceedings can only be entered with the consent of the government, whereas a plea of nolo contendere can be accepted by the court over the protestations of the prosecutor. Any characterization, therefore, of nolo as a "consent judgment" must be considered "an anomaly in legal parlance". ${ }^{68}$ In the last analysis, the court simply gave expression to congressional intent.

In view of the reported decisions, it would seem that, although some courts make a subtle distinction between permitting the actual guilt of the defendant to be shown after a nolo plea, and the fact of conviction after such a plea, the defendant cannot escape the fact that there has been conviction. Since a nolo plea is a conviction, it follows, then, that one who has so pleaded, would make a material misrepresentation

a defendant has violated said laws shall be prima facie evidence against such defendant in any suit or proceeding brought by any other party against such defendant under said laws as to all matters respecting which said judgment or decree would be an estoppel as between the parties thereto: Provided, This section shall not apply to consent judgments or decrees entered before any testimony has been taken."

63. Twin Ports Oil Co. v. Pure Oil Co., 26 F. Supp. 366, 376 (D. Minn. 1939); Barnsdall Refining Corp. v. Birnamwood Oil Co., 32 F. Sugp. 30S, 311 (E. D. Wis. 1940).

64. 38 Stat. 730 (1914), 15 U. S. C. $\$ 12$ (1940).

65. 26 Stat. 209 (1870), 15 U. S. C. $\$ 1$ (1940).

66. See note 59 supra.

67. Twin Ports Oil Co. v. Pure Oil Co., 26 F. Supp. 366, 376 (D. Minn. 1939).

68. See N. Y. Times, June 16, 1942, p. 30, col. 6, referring to United States v. American Waxed Paper Ass'n (Crim. E. D. Pa., Jan. 7, 1942) in which one trade association, 34 member companies and seventy of their exceutives pleaded nolo and paid $\$ 122,075$ in fines, and reporting: "Judge Bard declared there was 'no such thing as a consent judgment in a criminal proceeding' ...." 
in answering in the negative, the question, "Have you ever been convicted of a crime?"

Many judges will not accept the plea of nolo contendere, basing their refusal on the concededly logical premise that the accused is either guilty or not guilty. But the reported decisions meet this argument by holding that the fact of conviction is the same after a guilty plea as after a plea of nolo contendere. Other judges object to the plea on the ground that it is the result of a compromise between the prosecutor and the defendant, a transaction to which the court would prefer not to be a party. This argument is simply an emotional one, since such negotiations cannot conclude the court ${ }^{69}$ and there is nothing to prevent it from imposing the maximum punishment covered by the statute after the defendant has pleaded nolo.

The plea of nolo serves a practical function in the administration of justice. There are many situations, of which anti-trust prosecution is one, where the crime is considered malum prohibitum rather than malum in $s e^{70}$ and in such situations the prosecutor is often inclined to agree to the interposition of the nolo plea. This realistic policy dispenses with lengthy and expensive trials. A law enforcement agency having concurrent equitable and criminal power, like the Federal Anti-trust Division, frequently follows an indictment with a civil complaint, thereby seeking appropriate injunctive relief against the contintance of the offense charged in the indictment. Thus, the closing out of criminal cases by a nolo plea is simply preliminary to getting down to the job of eradicating the improper practices. At the same time, the pleader has paid his debt to society for past offenses and it can hardly be said that in making a nolo plea the accused leaves the question of his guilt undetermined.

69. United States v. Socony-Vacuum Oil Co., Inc., 23 F. Supp. 531, 532 (V. D. Wis. 1938).

70. Ibid. In this anti-trust case the Court stated:

"This case, however, lies in a field where the Government might, with cqual propriety, have proceeded initially by a civil action in equity, or, as here, by a criminal prosecution, either being an action to enforce penalties for the violation of a statutc. The Court is of the opinion that the wrong here complained of is not malum in se, but rather malum prohibitum, one peculiarly of an economic nature and one in which the attainment of a proper understanding between the parties is of itself a desirable end." 